salinity. Free sulphuretted hydrogen is not present, and although the water tastes strongly, no smell could be detected. It can be assumed that the sulphide is present as sodium sulphide, and this would also be in accordance with the $p \mathrm{H}$ value resulting from the hydrolytic dissociation of the corresponding amount of sulphide :

$$
\mathrm{Na}_{2} \mathrm{~S}+\mathrm{H}_{2} \mathrm{O}=\mathrm{NaSH}+\mathrm{NaOH} \text {. }
$$

The handbook refers to sulphuretted hydrogen in the water of Kalopanayotis, and remarks that the chief salts of the springs are the chlorides of sodium and magnesium, sulphate of magnesium and carbonate of lime.

Analytical data for these springs of this first group are shown in Table 1.

TABLE 1

\begin{tabular}{|c|c|c|c|c|}
\hline & Ayiasmata & Pelendri & Tiochou & Psammiacon \\
\hline Temperature & $23^{\circ} \mathrm{C}$. & $25 \cdot 5^{\circ} \mathrm{C}$ & $19 \cdot 7^{\circ} \mathrm{C}$ & 20.5 ${ }^{\circ} \mathrm{C}$.(Sept. \\
\hline Transparency & clear & clear & clear & clear \\
\hline Colour & colourless & colourless & colourless & colourless \\
\hline$p \mathrm{H}$ & $11 \cdot 3$ & $11 \cdot 4$ & $11 \cdot 6$ & . $11 \cdot 7$ \\
\hline $\begin{array}{l}\mathrm{KNO}_{3} \text { (mgm./l.) } \\
\mathrm{KCl}\end{array}$ & $\begin{array}{l}1 \cdot 5 \\
4 \cdot 5\end{array}$ & $9 \cdot 1$ & $26 \cdot 0$ & $61 \cdot 5$ \\
\hline $\mathrm{NaCl}$ & $335 \cdot 3$ & $207 \cdot 0$ & $722 \cdot 6$ & $698 \cdot 2$ \\
\hline $\mathrm{Na}_{2} \mathrm{~S}$ & $13 \cdot 1$ & $23 \cdot 4$ & $56 \cdot 1$ & $63 \cdot \overline{1}$ \\
\hline $\mathrm{Na}_{2} \mathrm{SO}_{4}$ & $31 \cdot \overline{3}$ & $29 \cdot 1$ & $43 \cdot \overline{5}$ & $36 \cdot \hat{9}$ \\
\hline $\mathrm{Na}_{2} \mathrm{CO}_{3}$ & $31 \cdot 5$ & $55 \cdot 5$ & $161 \cdot 0$ & $126 \cdot 1$ \\
\hline $\mathrm{CaSO}_{4}$ & $256 \cdot 3$ & $26 \cdot 6$ & $9 \cdot 2$ & $5 \cdot 8$ \\
\hline $\begin{array}{l}\mathrm{MgSO}_{4} \\
\mathrm{Al}_{2}\left(\mathrm{SO}_{4}\right)_{3}\end{array}$ & $\begin{array}{l}0.9 \\
1.5\end{array}$ & 二 & $\overrightarrow{1 \cdot 1}$ & $\overrightarrow{1 \cdot 1}$ \\
\hline Total Salines & $677 \cdot 9$ & $351 \cdot 3$ & $1,019 \cdot 5$ & $992 \cdot 7$ \\
\hline $\begin{array}{l}\mathrm{H}_{2} \mathrm{SiO}_{3} \\
\mathrm{HBO}_{2}\end{array}$ & $\begin{array}{r}10 \cdot 1 \\
2 \cdot 9\end{array}$ & $\begin{array}{r}25 \cdot 6 \\
4 \cdot 1\end{array}$ & $\begin{array}{l}64 \cdot 4 \\
11 \cdot 2\end{array}$ & $\begin{array}{r}69 \cdot 6 \\
7 \cdot 8\end{array}$ \\
\hline
\end{tabular}

The waters of the second group are slightly acid (almost neutral), and are nearly saturated with gypsum. The fact that these springs have their source in the gypsum rocks of the Idalian series explains satisfactorily the high calcium sulphate content. The water contains sulphuretted hydrogen as well as carbonic acid and bicarbonate, and smells and tastes of hydrogen sulphide. The presence of sulphide is probably due to the reduction of calcium sulphate with subsequent freeing of sulphuretted hydrogen through action of the carbonic acid.

Analytical data for the four springs of the second group are given in Table 2.

\begin{tabular}{|c|c|c|c|c|}
\hline & Lethimbou & $\underset{\text { Anargyroi }}{\text { Ayoi }}$ & Myrtos & Mathi \\
\hline $\begin{array}{l}\text { Temperature } \\
\text { Transparency } \\
\text { Colour } \\
p \mathrm{H} \\
\mathrm{KNO} \\
\mathrm{KCl}_{8}(\mathrm{mgm} . / 1 .) \\
\mathrm{NaCl} \\
\mathrm{CaSO} \\
\mathrm{Ca}\left(\mathrm{HCO}_{3}\right)_{2} \\
\mathrm{Mg}\left(\mathrm{HCO}_{3}\right)_{2} \\
\mathrm{Fe}\left(\mathrm{HCO}_{3}\right)_{2} \\
\mathrm{NaHCO}_{3} \\
\mathrm{MgSO}_{4}\end{array}$ & $\begin{array}{r}20 \cdot 2^{\circ} \mathrm{C} . \\
\text { very slight } \\
\text { turbidity } \\
\text { faint yellow } \\
6 \cdot 9 \\
\frac{2 \cdot 8}{115 \cdot 7} \\
2,189 \cdot 3 \\
105 \cdot 3 \\
267 \cdot 6 \\
2 \cdot 6 \\
\text { - }\end{array}$ & $\begin{array}{c}20 \cdot 5^{\circ} \mathrm{C} . \\
\text { clear } \\
\text { faint yellow } \\
7 \cdot 0 \\
0 \cdot 5 \\
13 \cdot 7 \\
163 \cdot 8 \\
2,075 \cdot 3 \\
141 \cdot 5 \\
2 \cdot 5 \\
272 \cdot 9 \\
277.5\end{array}$ & $\begin{array}{c}20.0^{\circ} \mathrm{C} . \\
\text { clear } \\
\text { colourless } \\
6 \cdot 9 \\
1 \cdot 7 \\
21 \cdot 8 \\
493 \cdot 8 \\
2,104 \cdot 7 \\
168 \cdot 2 \\
2 \cdot 4 \\
234.8 \\
219.0\end{array}$ & $\begin{array}{c}19 \cdot 5^{\circ} \mathrm{C} \text {.(Sept. } \\
\text { midday) } \\
\text { clear } \\
\text { colourless } \\
\frac{7 \cdot 1}{\overline{6} \cdot 9} \\
103 \cdot 4 \\
2,032 \cdot 0 \\
45 \cdot 4 \\
291 \cdot 5 \\
\text { traces } \\
= \\
-\end{array}$ \\
\hline Total Salines & $2,683 \cdot 3$ & $2,947 \cdot 7$ & $3,246 \cdot 3$ & $2,479 \cdot 2$ \\
\hline $\begin{array}{l}\mathrm{H}_{2} \mathrm{~S} \\
\mathrm{CO}_{2} \\
\mathrm{H}_{2} \mathrm{SiO}_{2} \\
\mathrm{H} \mathrm{BO}_{2}\end{array}$ & $\begin{array}{r}13 \cdot 6 \\
81 \cdot 7 \\
44 \cdot 5 \\
1 \cdot 2\end{array}$ & $\begin{array}{r}19 \cdot 0 \\
59 \cdot 7 \\
63 \cdot 2 \\
4 \cdot 9\end{array}$ & $\begin{array}{r}9 \cdot 9 \\
46 \cdot 6 \\
64 \cdot 6 \\
2 \cdot 4\end{array}$ & $\begin{array}{r}2 \cdot 7 \\
56 \cdot 3 \\
52 \cdot 9 \\
3 \cdot 6\end{array}$ \\
\hline
\end{tabular}

P.O.B. 30,

M. TAMari.

Larnaca.

May 29.

\section{Temperature of Flame Gases}

IN internal combustion engines the temperature of the flame gases is inferred from pressure and volume measurements and is therefore a measure of their mean molecular translational energy. In open flames, however, the temperature is generally assumed to be that acquired by a thermometric substance immersed in them (after correction for radiation loss). But the temperatures shown in the table below indicate that this requires further consideration. These temperatures were measured by means of very fine platinum-rhodium wires $(0.0005 \mathrm{in}$. diameter $)$ and quartz-covered platinum-rhodium wires $(0.0005$ in. overall diameter) during the pre-pressure period in large closed-vessel explosions ${ }^{1}$. No correction for radiation loss has been applied to them. The combustible gas-air mixtures were at atmospheric pressure and were thoroughly mixed before ignition by an electric spark.

\begin{tabular}{|c|c|c|c|c|}
\hline \multirow{2}{*}{\multicolumn{2}{|c|}{$\begin{array}{l}\text { Percentage } \\
\text { combustible gas } \\
\text { in mixture }\end{array}$}} & \multicolumn{3}{|c|}{ Temperature $\left({ }^{\circ} \mathrm{C}.\right)$ measured by } \\
\hline & & $\begin{array}{c}\text { Quartz } \\
\text { covered wire }\end{array}$ & Plain wire & Difference \\
\hline $\begin{array}{lll}20 \% & \mathrm{CO}^{*} & \ldots . \\
25 \% & \mathrm{CO}^{*} & \ldots \\
29.6 \% & \mathrm{CO}^{*}\end{array}$ & $\begin{array}{l}\ldots . . \\
\ldots . \\
\ldots .\end{array}$ & $\begin{array}{l}1,210 \\
1,350 \\
1,470\end{array}$ & $\begin{array}{l}1,420 \\
1,650 \\
1,850 \dagger\end{array}$ & $\begin{array}{l}210 \\
300 \\
380\end{array}$ \\
\hline $\begin{array}{lll}55 \% & \mathrm{CO}^{*} & \ldots \\
60 \% & \mathrm{CO}^{*} & \ldots .\end{array}$ & a.. & $\begin{array}{l}1,350 \\
1,260\end{array}$ & $\begin{array}{l}1,350 \\
1,260\end{array}$ & $\begin{array}{l}0 \\
0\end{array}$ \\
\hline 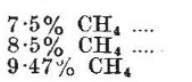 & $\begin{array}{l}\cdots . \\
\cdots \\
\cdots\end{array}$ & $\begin{array}{l}1,250 \\
1,320 \\
1,380\end{array}$ & $\begin{array}{l}1,440 \\
1,600 \\
1,730\end{array}$ & $\begin{array}{l}190 \\
280 \\
350\end{array}$ \\
\hline
\end{tabular}

* The carbon monoxide contained 1\% hydrogen.

t Slightly extrapolated.

There would have been little or no difference between the temperatures measured by the two wires had the flame gases been just hot normal gases. But as has been shown, flame gases contain a long-lived latent energy (probably resident within a proportion of the newly formed tri-atomic molecules) and in virtue of this an abnormal dissociation may obtain in them. It would appear, therefore, that a thermometric substance immersed in flame gases may be heated as a result of :

(I) their true temperature (proportional to their mean molecular translational energy),

(2) the unloading of latent energy upon its surface, and

(3) recombination of the abnormally dissociated products upon its surface, provided that this is of a type (like platinum) which promotes surface combustion.

The large differences between the uncoated and quartz-coated wires must be due mainly to (3). In the case of the 55 per cent and 60 per cent carbon monoxide mixtures it will be noted that there is no difference between the temperatures measured by the two wires, and in these cases it must be supposed that the abnormal dissociation is suppressed by the large excess of carbon monoxide.

\section{W. T. David.}

Engineering Department, University,

Leeds, 2.

August 4.

1 "The Abnormality of Flame Gases", Proc. I. Mech. Eng. (in press) and other papers referred to therein. 